\title{
Global partnership for sustainable development: challenges and perspectives for Ukraine
}

\author{
Iryna Honcharenko ${ }^{1}$, Olena Berezina ${ }^{1,{ }^{*}}$, Lesya Berezhna ${ }^{1}$, and Victoria Zhuk $^{2}$ \\ ${ }^{1}$ Cherkasy State Technological University, Finance Department, 18006, Cherkasy, 460 blvd. \\ Schevchenko, Ukraine \\ ${ }^{2}$ Educational and Scientific Institute of Administration, Economics and Nature Management, \\ V. I. Vernadsky Taurida National University, Department of Hospitality Industry and Sustainable \\ Development Sciences, 01042, Kyiv, 33 John McCain street, Ukraine
}

\begin{abstract}
Research background: The global concept of sustainable development was elaborated in detail by the UN and the Club of Rome. Development Agenda 2030 and 17 Sustainable Development Goals (SDG) were adopted in 2015 with the main priorities of social development of the world. The monitoring and analysis of the 17 SDG and 169 targets of the new agenda will be carried out through a set of global indicators.

Purpose of the article is to develop a system of indicators for monitoring the achieving the SDG in Ukraine. This system will use for estimating the current results and developing mid-term forecast.

Methods: The classical econometric methods and models, in particular, the exponential smoothing method was used for estimating and forecasting. Also, the multidimensional ranking and the method of expert assessments were used. The research is carried out based on statistical data (from 2008 to 2018 years) of the State Statistics Service of Ukraine, Ministry of Economic Development and Trade of Ukraine, UN reports.

Findings \& Value added: The article contains an overview of the essence, components, aims, methodology, results and forecast for achieving the 17th Sustainable Development Goal "Global Partnership" in Ukraine. The system of individual \& integrated indicators for the global partnership was built for evaluating the current results and using for forecast modelling. The model of global partnership and mid-term forecast for Ukraine was built for the paper's aim achieving. The results showed the main challenges for Ukraine in achieving the 17th SDG soon.
\end{abstract}

Keywords: global partnership; sustainable development; sustainable development goals (SDG), adaptive forecasting models

JEL Classification: C52; C53; E27; F55; F62

\footnotetext{
*Corresponding author: o.berezina@chdtu.edu.ua
} 


\section{Introduction}

The contemporary concept of sustainable development has systematically combined three main components: economic, environmental and social. The economic approach based on optimal using of limited resources as well as material-saving and energy-saving technologies for creating the aggregate income flow that would preserve (not reduce) the aggregate capital (physical, natural or human) for generating that aggregate income. Environmental component grounded the integrity of biological and physical natural systems, their viability, on which the global stability of the entire biosphere depends. The social component is focused on human development, on maintaining the stability of social and cultural systems, on reducing the number of conflicts.

The formation of the sustainable development concept as a global understanding of the social progress path for the future began in the 1960s. However, many works of philosophers, sociologists, economists of the past are the scientific basis for the formation of this concept, along with many legislative acts of national and international levels, which laid the normative basis for responsible human use of available resources in economic activity. In the second half of the twentieth century, when the negative consequences of the industrial revolution, the irresponsible use of renewable and non-renewable resources for economic benefits, the destruction of self-regulatory mechanisms of ecological systems, led to many local social and environmental crises worldwide, the cognizance to the idea of intelligent coexistence of human and nature significantly increased. The report of the Club of Rome "The Limits to Growth" (1972) [1] highlighted the problem of limited natural resources, their inaccessibility for future generations, as well as a significant and uncontrollable decline in population by 2070 while maintaining trends of industrialization, environmental pollution, food production and resource depletion. These problems erased in two another significant works on sustainable development: B. Ward and R. Dubos "Only One Earth - The Care and Maintenance of a Small Planet" [2], P. Ehrlich "How to Be a Survivor: A Plan to Save Spaceship" [3].

The prospects for the development of civilization in the face of the depletion of natural resources, increasing environmental pollution and continued population growth were raised in the UN Conference on the Environment (1972, Stockholm). The Conference adopted an action plan with 109 points of recommendation addressed to national governments and international organizations, and proposed the establishment of a new mechanism in the UN system that would facilitate the implementation of decisions in concrete actions of a political and scientific nature. WCED in 1987 introduced the report "Our Common Future" [4], emphasized on the need for sustainable development as development that provides the needs of the present generations without damage interests and the possibility of future generations to meet their own needs. This formulation of the concept widely used nowadays as a basis in many countries, including the EU Sustainable Development Strategy until 2020 [5].

The UN Conference in Rio de Janeiro (1992) declared the need to recognize the principles of sustainable development as key guidelines for the formation of a new society. Sustainability is a simple concept: to live injustice within our environmental capabilities [6]. In 2002 the three components of sustainable development are reflected in the Agenda 21 [7] as the plan with three levels: global, national and regional. The 21 Agenda identifies information, integration and participation as the three key blocks needed to achieve sustainable development, and emphasizes the need to replace old ways of doing business with new ones (based on cross-sectoral interaction and integration of approaches to environmental protection and reduction of social contradictions in the process of development), broad public participation in decision-making. Adopted in 2000 by 189 nations at the UN Millennium Summit, the UN Millennium Declaration identified the 
Millennium Development Goals (MDGs), a comprehensive framework of core values, principles and key drivers through 2015. As soon as the universal MDGs framework was designed, many countries worldwide refined the MDGs and established country-specific development targets. The issues of the UN Summit (2015, New York) covered all aspects of socio-economic development, country competitiveness, environmental and energy security, the global partnership for development, and the amount of thorough preparatory work was unprecedented in history. The results of the summit was the 2030 Agenda (Transforming our world: the 2030 Agenda for Sustainable Development) [8] and seventeen Sustainable Development Goals (SDGs) [9], which is a top priority of social development. In the SDGs, in contrast to the MDGs, the list of areas and tasks has been expanded. This approach is justified and confirmed that nowadays in the globalized world, sustainable development isn't possible without peace and security, as well as the establishment of global partnership. The SDGs provide guidelines for policy-making and funding under the relevant programs of UNDP, the main UN development agency, and provide support to national governments on adopting and implementing the goals. The 2030 Agenda [8] commits each country to a wide range of measures aimed not only at eradicating the causes of poverty but also at ensuring economic growth and prosperity and meeting people's health needs, education and social security with the unconditional provision of environmental protection. The document recognizes that the world faces global challenges, from poverty, growing inequality and colossal disparities in opportunities, wealth and power to environmental degradation and the risks posed by climate change.

Analysis of 17 SDGs and 169 tasks of sustainable development, as well as their relationship and consistency with the principles of sustainable development and the MDGs, allowed to state a more balanced social (8), economic (6) and environmental (8) component in the SDGs $(8 ; 6 ; 8)$ compared to the basic principles of sustainable development $(13 ; 16$; $19)$ and the MDGs $(6 ; 1 ; 1)$. The last two SDGs $(16,17)$ "Peace, Justice and Strong Institutions", "Partnership for Sustainable Development" hold the basic function of ensuring the achievement of other goals. Each country, having identified from the list of SDGs and tasks the most priority for itself, determines its priorities for sustainable development, and develops strategic documents, sets goals and elaborates plans to achieve them at the national and regional levels. The dominant economic preferences by countries and nations, investigated by A.Falk, A. Becker, T. Dohmen et al [10] helps to correlate SDGs, national priorities with human behaviour and expectations at the national, regional and local level. The UN proposed to use a set of global indicators for monitoring of 2030 Agenda success. However, the indicators developed by the UN for monitoring are not always acceptable in the national context: the system of global SDGs indicators, based on the results of the 47th plenary session of the UN Statistical Commission, contains a total of 240 indicators. The peculiarities of achieving SDGs in different countries, as well as challenges of estimating the success with the UN indicators at the national level described by S. Zaini and A. Akhtar [11], A. Kassenberg [12], V.Urazgaliev and G.Menshikova [13], M Biggery, D.A. Clark et al [14], E. B. Barbier and J. C. Burgess [15], A. Miola and F. Schiltz [16], R. Hayman [17]. Most commonly, the system of indicators for monitoring and assessing the sustainability of development is also being developed at the national level.

The globalization of the economy, the transformation of economic systems has led to the organization in countries a system of relations based on strategic alliances and cooperation at both local and global levels. Chops and changes in the geopolitical situation in the world, violations of international agreements, the destruction of peaceful relations, increasing disparities in the development of different countries have exacerbated the global problems of society associated with numerous social, economic and environmental challenges. At the same time, global trends indicate the simultaneous development of global processes of integration and localization, which are the main criteria and principles 
of the modern world development. The global partnership ensures unity and integrity and helps to level down conflicts of interest and reach the consensus in the vision of a common future. The research of the transnationalisation impact on the development of the national economy of Ukraine [18] and practices of European integration [19] et al. grounded that the experience that Ukraine has gained in international partnership at the cross-border level is promising. It has participated in the creation of 10 European regional projects. Among these, it has successfully cooperated in such areas as solving regional environmental problems, the development of human communication (tourism, local border traffic) and cooperation in scientific and educational spheres. This paper aimed at evaluating the success in achieving SDG 17 "Partnership for Sustainable Development" in Ukraine, as well as on identifying main challenges and perspectives, because the potential of global partnership remains insufficient today.

\section{Methods}

The classical econometric methods and models, in particular the exponential smoothing method, the multidimensional ranking and the method of expert assessments were used for estimating and forecasting. The exponential smoothing method refers to adaptive prediction models that can quickly work out the structure and parameters to change external conditions. The utilizing of these methods is due to the peculiarity of macroeconomic data, which are used in the calculation of indicators and which are constantly changing under the influence of external factors. In the situation when the recent implementation of the investigational process is the most important, the adaptive methods are the most effective, take due account the disparity among time series. The disadvantage of these methods is the short-term forecast (maximum 3 periods). However, given the constant changes in Ukraine's economy caused by many internal and external factors, predicting the trend of change until 2030 is meaningless. That is why the choice for the calculations of Brown's linear model is reasonable.

The construction of the Indicator for assessment the achieving the SDG $17\left(I_{17}\right)$ contains the following stages:

1. Formation of a set of indicators. Three main targets $(17.1,17.2,17.3)$ and four indicators $(17.1 .1 .3,17.1 .2 .1,17.2 .1 .3,17.3 .1 .1)$ for SDG 17 elaborated in Ukraine National Baseline Report for SDGs [20]. Four additional indicators (17.1.1.1, 17.1.1.2, 17.2.1.1, 17.2.1.2) added by authors for the forecast, table 1.

Table 1. Targets and indicators for SDG 17 "Partnership for Sustainable Development"

\begin{tabular}{|l|l|}
\hline 17.1. & $\begin{array}{l}\text { Mobilize additional financial resources by promoting foreign and domestic } \\
\text { investment }\end{array}$ \\
\hline 17.1.1.1 & Private remittances to Ukraine, mln.USD \\
\hline 17.1.1.2 & GDP at actual prices, mln. USD \\
\hline 17.1.1.3 & The ratio of private remittances from abroad to GDP, $\%$ \\
\hline 17.1 .2 .1 & Net foreign direct investment (according to BOP), bln.USD \\
\hline 17.2. & Consistently reduce the debt burden on the economy \\
\hline 17.2.1.1 & The ratio of gross external debt, million USD \\
\hline 17.2.1.2 & Exports of goods and services, mln. USD \\
\hline 17.2.1.3 & The ratio of gross external debt to exports of goods and services (annual) \\
\hline 17.3. & Develop a partnership between government and business to achieve the SDGs \\
\hline 17.3.1.1 & Number of public-private partnership projects \\
\hline
\end{tabular}

Source: Sustainable Development Goals: Ukraine. National Baseline Report, own processing

2. Normalization and standardization of indicators. The feature vector for $I_{17 i}$ consists of four indicators $(17.1 .1 .3,17.1 .2 .1,17.2 .1 .3,17.3 .1 .1)$. Whereas of its relative simplicity 
and tractability does not require the development of a structural and hierarchical scheme for integral index. Also, all these macroeconomic indicators can be considered as equilibrium table 2 .

Table 2. Transformation of indicators for integrated indicator $I_{17 i}$

\begin{tabular}{|l|c|r|}
\hline \multicolumn{1}{|c|}{ Indicator } & Orientation & Transformation (standardization) \\
\hline $\begin{array}{l}\text { 17.1.1.3 The ratio of private remittances } \\
\text { from abroad to GDP,\% }\end{array}$ & $\begin{array}{c}\uparrow-\text { stimulant } \\
\left(x_{i 1}\right)\end{array}$ & $\begin{array}{r}z_{i 1}=\frac{x_{i 2}}{a}, \\
\text { where } a \text { is the target in the } i \text {-th year }\end{array}$ \\
\hline $\begin{array}{l}\text { 17.1.2.1 Net foreign direct investment } \\
\text { (according to BOP), bn. USD }\end{array}$ & $\begin{array}{c}\uparrow-\text { stimulant } \\
\left(x_{i 2}\right)\end{array}$ & $\begin{array}{r}z_{i 2}=\frac{x_{i z}}{a} \\
\text {, }\end{array}$ \\
\hline $\begin{array}{l}\text { 17.2.1.3 The ratio of gross external debt } \\
\text { to exports of goods and services in annual } \\
\text { terms }\end{array}$ & $\begin{array}{c}\downarrow-\text { disincentive } \\
x_{i 3}^{\prime}=\frac{100}{x_{3}} \rightarrow \uparrow\end{array}$ & $\begin{array}{r}z_{i 3}=\frac{x_{i z}^{\prime}}{a}, \\
\text { where } a \text { is the target in the } i \text {-th year }\end{array}$ \\
\hline $\begin{array}{l}\text { 17.3.1.1 Number of public-private } \\
\text { partnership projects }\end{array}$ & $\begin{array}{c}\uparrow-\text { stimulant } \\
\left(x_{i 1}\right)\end{array}$ & $\begin{array}{c}z_{i 4}=\frac{x_{i 4}}{a}, \\
\text { where } a \text { is the target in the } i \text {-th year }\end{array}$ \\
\hline
\end{tabular}

Source: own processing

As it is known, the task of normalization is the transition to this scale of measurement, when the "best" indicator corresponds to the value of 1 and a "bad" value is 0 . All proposed indicators are stimulants, except the indicator 17.2.1. This indicator has a different focus than other indicators for which growth is a positive result, it converted into a stimulant. Moreover, the indicators for assessing the $I_{17 i}$ have different units of measurement. Accordingly, the additive aggregation requires bringing them to one basis, i.e. preliminary standardization, according to the formula:

$$
z_{i j}=\frac{x_{i j}}{a},
$$

where $i$ - the $\operatorname{year}(i=\overline{1,5}) ; j-$ the indicator $(j=\overline{1,3})$ (see table 2$)$. The peculiarity of the feature vector is a comparison of the level of its compliance with the target value. Therefore, in formula (1) the value of $a$ is a certain reference (target) value from table w, and the results of the calculations will show:

$Z_{i j}<1$ - the indicator below the target (negative level of achieving the SDG 17);

$Z_{i j}=1-$ the indicator corresponds to the target (satisfactory level of achieving the SDG 17);

$Z_{i j}>1$ - the indicator above the target benchmark (high level of achieving the SDG 17).

Calculation of the integral index $I_{17 i}$ proposed to build as the arithmetic average of the standardized values $z_{i j}$ according to the following formula:

$$
I_{17 i}=\frac{1}{m} \sum_{1}^{j} z_{i j}=\frac{z_{i 1}+z_{i 2}+z_{i 3}+z_{i 4}}{4}
$$

3. Calculation of the integrated index based on data. The research is carried out based on statistical data (from 2008 to 2018 years) of the National Bank of Ukraine [21, 22], the State Statistics Service of Ukraine [23], Ministry of Economic Development and Trade of Ukraine, UN reports at al.

\section{Results and Discussions}

Like the other UN Member States, Ukraine joined the global process of sustainable development. A participatory and inclusive process to adapt the SDGs to the Ukrainian 
context was launched to establish a national strategic framework for Ukraine up to 2030 based on the principle 'leave no one behind'. Every global target was reviewed, taking into consideration the specific national context. In 2016, Ukraine held four national and ten regional consultations [20]. The result of this work was the national system of SDG, which consists of 86 tasks of national development. The SDGs should ensure the national integration of efforts for economic growth, a commitment to social justice and the need for environmental management.

The main document that determines the motion vectors of Ukraine to sustainable development was adopted in January 2015, the sustainable development Strategy "Ukraine2020 ' [24]. The aim of the Strategy is the implementation in Ukraine of European standards of living and entry into the leading position in the world. Four main vectors of the progressive development of the country are defined in this document: 1) the development vector is the sustainable development of the state, structural reforms and, as a consequence, raise of living standards; 2) the security vector is safeguarding the security of the state, business and citizens, the security of investments and private property; 3) the responsibility vector is the guarantee that every citizen, regardless of race, colour, political, religious and other beliefs, sex, ethnic and social origin, property status, domicile, linguistic or other characteristics will have an access to high-quality education, health care and other services in the public and private sectors; 4) the pride vector is mutual respect and tolerance in society, pride in own country, its history, culture, science, sports.

Table 3 reports three main targets and four indicators for SDG 17 elaborated in Ukraine National Baseline Report for SDGs [20].

Table 3. Targets and indicators for SDG 17 "Partnership for Sustainable Development"

\begin{tabular}{|c|c|c|}
\hline Task & Indicator & Target values \\
\hline \multirow{2}{*}{$\begin{array}{l}\text { 17.1. Mobilize additional financial resources } \\
\text { by promoting foreign and domestic } \\
\text { investment }\end{array}$} & $\begin{array}{l}\text { 17.1.1.3 The ratio of private } \\
\text { remittances from abroad to } \\
\text { GDP, } \%\end{array}$ & $\begin{array}{l}2015-5.75 \\
2020-6.00 \\
2025-6.00 \\
2030-6.00 \\
\end{array}$ \\
\hline & $\begin{array}{l}\text { 17.1.2.1 Net foreign direct } \\
\text { investment (according to BOP), } \\
\text { USD billions }\end{array}$ & $\begin{array}{l}2015-3.0 \\
2020-10.0 \\
2025-16.0 \\
2030-17.5 \\
\end{array}$ \\
\hline $\begin{array}{l}\text { 17.2. Consistently reduce the debt burden on } \\
\text { the economy }\end{array}$ & $\begin{array}{l}\text { 17.2.1.3 The ratio of gross } \\
\text { external debt to exports of goods } \\
\text { and services in annual terms }\end{array}$ & $\begin{array}{l}2015-28.2 \\
2020-18.0 \\
2025-11.0 \\
2030-7.0 \\
\end{array}$ \\
\hline $\begin{array}{l}\text { 17.3. Develop a partnership between } \\
\text { government and business to achieve the } \\
\text { SDGs }\end{array}$ & $\begin{array}{l}\text { 17.3.1.1 Number of projects } \\
\text { public-private partnership, units }\end{array}$ & $\begin{array}{l}2015-5 \\
2020-15 \\
2025-30 \\
2030-45\end{array}$ \\
\hline
\end{tabular}

Source: Sustainable Development Goals: Ukraine. National Baseline Report

To ensure sustainable development of the state and the successful implementation of this Strategy 62 reforms and programs of the state development must be brought into action, among which ten priority programs are outlined. Undoubtedly, the successful implementation of reforms and achievement of all development objectives is good governance, eradication of corruption, public support. Accordingly, a social integration, good governance, honest and transparent government, public participation in decisionmaking and monitoring of their implementation, social dialogue is fundamental to the sustainable development of a country and its regions [25].

A review of the information available in Ukraine to monitor the global SDG indicators shows that the current government statistics agencies collect information on 96 indicators. 
52 indicators comply fully with existing international standards, while 44 indicators are in incomplete (partial) compliance with existing international standards. The total number of indicators to determine the success of the SDG at the national level for full monitoring and relevant reports, which will be the basis for strategic and tactical actions for sustainable development of Ukraine and its regions and implementation numerous regulations is 172 .

Figures 1-4, table 4 reports of fact and target values of SDG 17 indicators, it's dynamic from 2008 till 2019 and forecasts until 2022.

Table 4. SDG 17 indicators for the period 2008-2019

\begin{tabular}{|c|c|c|c|c|c|c|}
\hline Year / Indicator & 2008 & 2009 & 2010 & 2011 & 2012 & 2013 \\
\hline 17.1 .1 .1 & 6177 & 5370 & 5862 & 7019 & 7526 & 8537 \\
\hline 17.1 .1 .2 & 196201.8 & 1797992 & 136012.5 & 163160.4 & 175780.7 & 183310.1 \\
\hline 17.1 .1 .3 & 3.15 & 2.99 & 4.31 & 4.3 & 4.28 & 4.66 \\
\hline 17.1 .2 .1 & 10.7 & 4.77 & 6.45 & 7.21 & 8.18 & 4.51 \\
\hline 17.2 .1 .1 & 101743 & 103432 & 117346 & 126236 & 134625 & 142079 \\
\hline 17.2 .1 .2 & 82480 & 52080 & 65626 & 83652 & 86516 & 81719 \\
\hline 17.2 .1 .3 & 21.05 & 40.51 & 38.41 & 30.14 & 31.33 & 42.33 \\
\hline 17.3 .1$. & - & - & - & - & 111 & 159 \\
\hline Year/Indicator & 2014 & 2015 & 2016 & 2017 & 2018 & 2019 \\
\hline 17.1 .1 .1 & 6489 & 6959 & 7535 & 9264 & 11111 & 12017 \\
\hline 17.1 .1 .2 & 133503.9 & 91031 & 93355.87 & 112190.3 & 130832.4 & 153781.1 \\
\hline 17.1 .1 .3 & 4.86 & 7.64 & 8.07 & 8.26 & 8.49 & 7.8 \\
\hline 17.1 .2 .1 & 0.85 & 3.05 & 3.44 & 2.83 & 2.48 & 3.04 \\
\hline 17.2 .1 .1 & 125297 & 117668 & 112524 & 115451 & 114710 & 121739 \\
\hline 17.2 .1 .2 & 65436 & 47862 & 46008 & 53868 & 59135 & 63421 \\
\hline 17.2 .1 .3 & 29.37 & 55.16 & 23.20 & 20.70 & 20.68 & 20.1 \\
\hline 17.3 .1 .1 & 171 & 177 & 186 & 191 & 189 & 187 \\
\hline
\end{tabular}

Source: National Bank of Ukraine, State Statistics Service of Ukraine, own processing

The indicator 17.1.1 "The ratio of private remittances from abroad to GDP, \%" (fig. 1) and 17.3.1 "The number of projects in public-private partnership" (fig. 3) is much higher and on targets throughout the study period. The same trend will continue soon (2020-2022 years), which is positive for Ukraine in terms of mobilization of additional financial resources. However, the indicator 17.1.2.1 "Net foreign direct investment (according to BOP) USD, billion" only in 2015 prevailed target is the value of 3 USD billions. Throughout the rest of the period, there is a significant deviation from the targets, which will negatively affect the task of mobilizing additional financial resources based on encouraging investment by foreign investors, figure 2 . The investment processes in the country show significant instability. The propensity to invest remains low: in 2015, gross fixed capital accounted for only $13.3 \%$ of GDP. The dynamics of capital investment depend heavily on market fluctuations. Between 2013 and 2015, they dropped by $33 \%$, and only started showing some growth in 2016. 


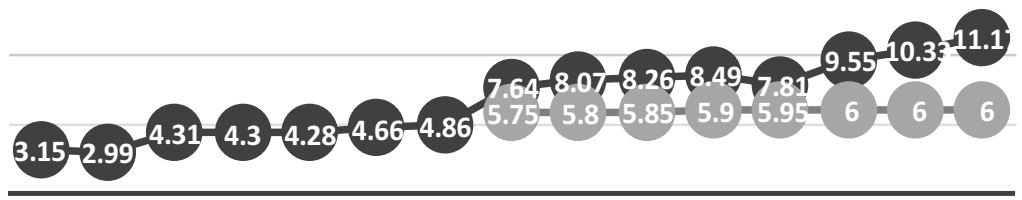

200820092010201120122013201420152016201720182019202020212022

The ratio of private remittances from abroad to GDP,\% - Target value

Fig. 1. Dynamic of actual, target and forecast value for indicator 17.1.1.3

Source: National Bank of Ukraine, State Statistics Service of Ukraine, own processing

The low investment attractiveness of the Ukrainian economy leads to a lack of foreign direct investment to restore the capacity of the national economy. As of 1 January 2016, Ukraine's economy attracted USD 36.1 billion of foreign direct investment, or USD 847.2 per capita - the lowest level in Europe. $31.8 \%$ of all foreign direct investment was in the real sector of the economy (industry, agriculture and construction) [25].

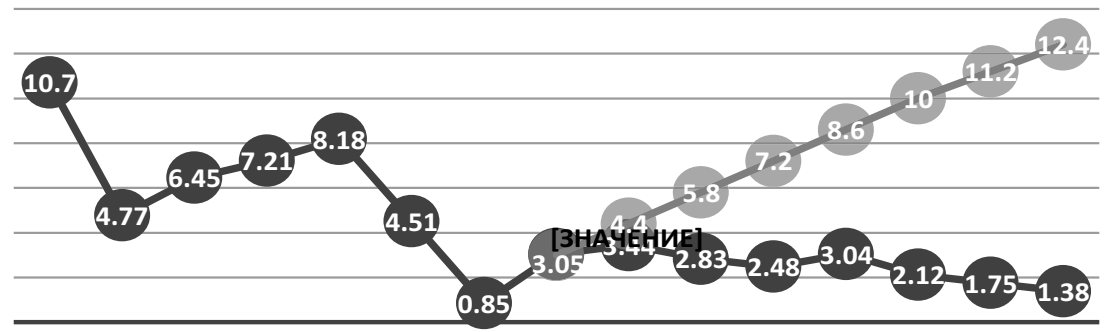

200820092010201120122013201420152016201720182019202020212022

$\longrightarrow$ Net foreign direct investment (according to EPA), bln.USD $\longrightarrow$ Target value

Fig. 2. Dynamic of actual, target and forecast value for indicator 17.1.2.1

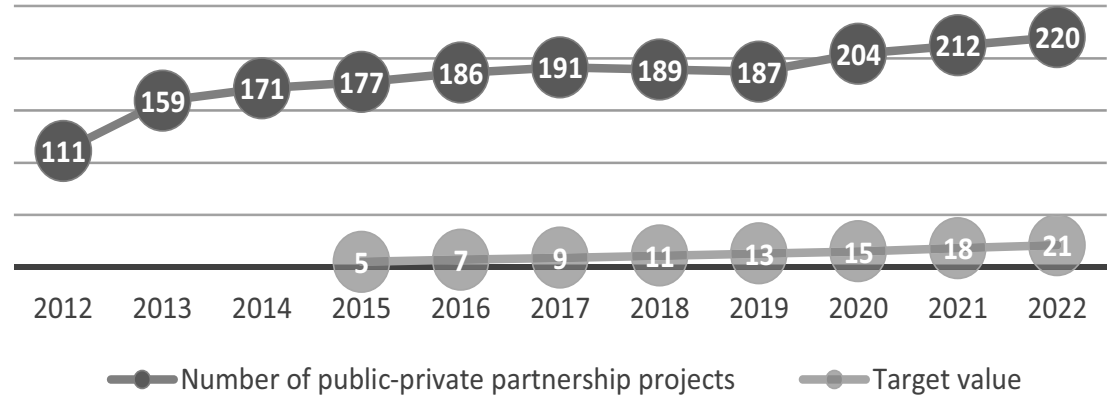

Fig. 3. Dynamic of actual, target and forecast value for indicator 17.3.1.1

Source: National Bank of Ukraine, State Statistics Service of Ukraine, own processing 
The 17.2.1.3 indicator "The ratio of gross external debt to exports of goods and services in annual terms" served its real value targets only during 2016-2019 years (see table 4). The next step call for aggregating all analyzed indicators into one integrated index with economic and mathematical methods of multidimensional ranking, table 5.

Table 5. Results of calculation of indicators 17.1.1.3, 17.1.2.1, 17.2.1.3, 17.3.1.1 values

\begin{tabular}{|c|c|c|c|c|c|c|c|c|}
\hline Indicator / Year & 17.1.1.3 & $\begin{array}{c}\text { TV } \\
17.1 .1 .3^{*}\end{array}$ & 17.1.2.1 & $\begin{array}{c}\mathrm{TV} \\
17.1 .2 .1^{*}\end{array}$ & 17.2.1.3 & $\begin{array}{c}\text { TV } \\
17.2 .1 .3^{*}\end{array}$ & 17.3.1.1 & $\begin{array}{c}\text { TV } \\
17.3 .1 .1^{*}\end{array}$ \\
\hline 2015 & 7.64 & 5.75 & 3.05 & 3 & 55.16 & 28.2 & 177 & 5 \\
\hline 2016 & 8.07 & 5.8 & 3.44 & 4.4 & 23.2 & 26.16 & 186 & 7 \\
\hline 2017 & 8.26 & 5.85 & 2.83 & 5.8 & 20.7 & 24.12 & 191 & 9 \\
\hline 2018 & 8.49 & 5.9 & 2.48 & 7.2 & 20.68 & 22.08 & 189 & 11 \\
\hline 2019 & 7.81 & 5.95 & 3.04 & 8.6 & 19.74 & 20.04 & 187 & 13 \\
\hline 2020 (forecast) & 9.55 & 6 & 2.12 & 10 & 23.86 & 18 & 204 & 15 \\
\hline 2021 (forecast) & 10.33 & 6 & 1.75 & 11.2 & 22.94 & 16.6 & 212 & 18 \\
\hline 2022 (forecast) & 11.17 & 6 & 1.38 & 12.4 & 22.03 & 15.2 & 220 & 21 \\
\hline
\end{tabular}

* Indicators' target values (TV) calculated based on the analysis of their growth rates for every five years respectively (see table 3 ).

Source: National Bank of Ukraine, State Statistics Service of Ukraine, own processing

Table 6 represents the results of normalization for disincentive indicator 17.2.1.3 "The ratio of gross external debt to exports of goods and services in annual terms".

Table 6. Normalization of the indicator 17.2.1.3

\begin{tabular}{|c|c|c|}
\hline & The normalized value of the indicator & The normalized target value of the indicator \\
\hline$x_{32015}^{\prime}$ & 1.81 & 3.55 \\
\hline$x_{32016}^{\prime}$ & 4.31 & 3.82 \\
\hline$x_{32017}^{\prime}$ & 4.83 & 4.15 \\
\hline$x_{32018}^{\prime}$ & 4.84 & 4.53 \\
\hline$x_{32019}^{\prime}$ & 5.07 & 4.99 \\
\hline$x_{32020}^{\prime}$ & 4.19 & 5.56 \\
\hline$x_{32021}^{\prime}$ & 4.36 & 6.02 \\
\hline$x_{32022}^{\prime}$ & 4.54 & 6.58 \\
\hline
\end{tabular}

Source: own processing

Table 7 represents results of the calculation for eight years according to formula (1), (2), the normalized components of the Integral index $I_{17 i}$. The obtained results show that over 2015-2019 years. Ukraine, despite the lack of value of the indicator 17.1.2.1 achieved SDG 17 compliance level above 1. It was caused in the main by the high rate of 17.3.1.1 indicator that may indicate the wrongheaded low level of the target, settled during the planning period. Thus, according to the data of State Statistics Service of Ukraine [23], this indicator for 2020 established by the government is 205 projects, while in the National Baseline Report [20] it provides for 15 projects. Ukraine has developed a legal framework for public-private partnerships, but the pace of its practical application is unsatisfactory. The existing projects are mostly related to ongoing public procurement and contain no tangible investment components. Today, there are no examples of stable partnership practices between public authorities and civil society institutions in areas such as public policy and the monitoring and public oversight of central executive authorities, local governments, institutions with budget financing etc. 
Table 7. Standardization and integrated assessment of $I_{17 i}$

\begin{tabular}{|l|c|c|c|c|c|}
\hline Standardized values of indicators & 17.1 .1 .3 & 17.1 .2 .1 & 17.2 .1 .3 & 17.3 .1 .1 & $I_{17 i}$ \\
\hline$z_{2015 j}$ & 1.33 & 1.02 & 0.51 & 3.54 & 1.599 \\
\hline$z_{2016 j}$ & 1.39 & 0.78 & 1.13 & 2.66 & 1.489 \\
\hline$z_{2017 j}$ & 1.41 & 0.49 & 1.17 & 2.12 & 1.297 \\
\hline$z_{2018 j}$ & 1.44 & 0.34 & 1.07 & 1.72 & 1.142 \\
\hline$z_{2019 j}$ & 1.31 & 0.35 & 1.02 & 1.44 & 1.030 \\
\hline$z_{2020 j}$ & 1.59 & 0.21 & 0.75 & 1.36 & 0.980 \\
\hline$z_{2021 j}$ & 1.72 & 0.16 & 0.72 & 1.18 & 0.945 \\
\hline$z_{2022 j}$ & 1.86 & 0.11 & 0.69 & 1.05 & 0.928 \\
\hline
\end{tabular}

Source: own processing

The situation with integrated index I17i much worse $(I 17 \mathrm{i}<1,0)$ and tends to decrease due to the decline in GDP and other macroeconomic indicators, figure 4.

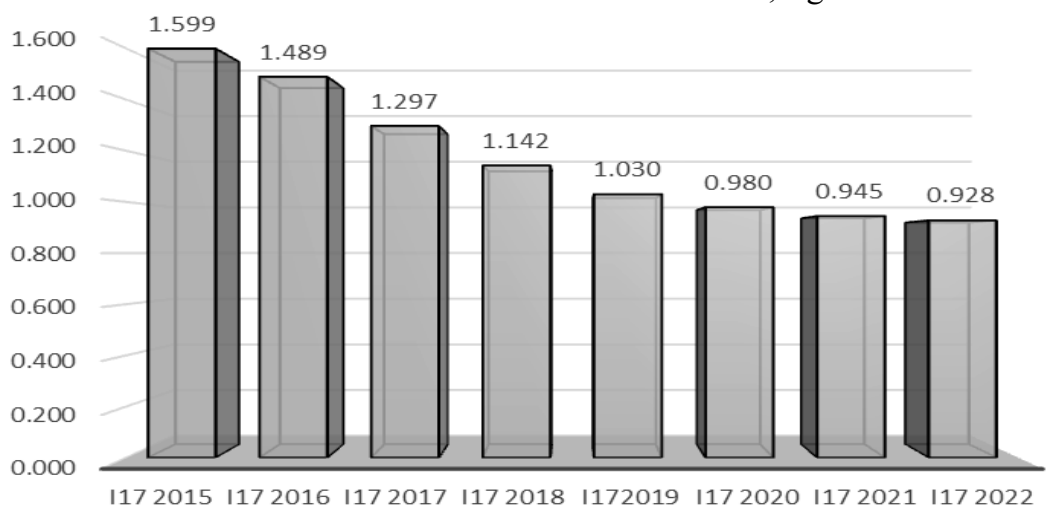

Fig. 4. Dynamic of the integrated index $I_{17 i}$

Source: own processing

\section{Conclusions}

Achieving the SDGs in Ukraine will be possible after the country resolves the problem of its limited resource capacity and the lack of appropriate institutional mechanisms to ensure the optimal, focused use of those resources. The lack of investment results in its focus on areas that are keys to the development of that particular sector. Instead, the level of investment in the system components of sustainable development (resource efficiency, reducing environmental impacts, development of social infrastructure etc.) remains low for both private and public investment.

It is necessary to implement targeted investment policies that would enhance the motivation to make and consolidate investments in innovative directions relevant to achieving the SDGs. For each of the potential sources of capital investment, a targeted approach that focuses on investment and the optimal use of rather limited resources should be applied. It is important to correct investment preferences by taking into consideration the need for investment in innovation. Given the difficult financial situation in Ukraine, 
enhancing cooperation with international organizations is still an important objective. It is advisable to improve the monitoring and oversight of the targeted goals.

Thus, the obtained results showed an inability to meet SDG 17 in Ukraine until 2022 without the turn of the tide. Key recommendations for achieving the goal is the following: strengthen the partnership principles of public organizations, and develop public-private partnerships; set up international cooperation; develop a networked society.

\section{References}

1. Meadows, D.H., Meadows, D.L., Randers, J., Behrens III, W.W. (1972). The Limits to Growth: a report for the Club of Rome's project on the predicament of mankind. NY: Universe Books.

2. Ward, B., Dubos, R. (1972). Only One Earth - The Care and Maintenance of a Small Planet. Norton: Maurice F. Strong.

3. Ehrlich, P. (1971). How to Be a Survivor: A Plan to Save Spaceship Earth. London: Ballantine Books.

4. Our Common Future: Report of the World Commission on Environment and Development (1987). Retrieved from: http://www.un-documents.net/our-commonfuture.pdf

5. Europe 2020 strategy (2012). Retrieved from: http://www.cbss.org/wpcontent/uploads/2012/ 12/Europe-2020-Strategy.pdf.

6. UN Documents: Sustainable Development. Retrieved from: http://www.un-documents. net/k-001303.html.

7. United Nations Sustainable Development Knowledge Platform. Retrieved from: http://sustainabledevelopment.un.org.

8. Transforming our world: The 2030 Agenda for sustainable development. Resolution adopted by the General Assembly on 25 September 2015/A/RES/70/1. (2015). Retrieved from: https://documents-dds-ny.un.org/doc/UNDOC/GEN/N15/291/89/PDF/ N1529189.pdf?Open Element.

9. Sustainable Development Goals. Retrieved from: http://www.un.org.ua/ua/tsilirozvytku-tysiacholittia/tsili-staloho-rozvytku.ň

10. Falk, A., Becker, A., Dohmen, T., Enke, B., Huffman, D., Sunde, U. (2018). Global Evidence on Economic Preferences. The Quarterly Journal of Economics, 133(4), 16451692.

11. Zaini, S.H. R., Akhtar, A. (2019). Modelling the Sustainable Development Goals for India - An Interpretive structural modelling Approach. World Review of Science, Technology and Sustainable Development, 15, 46-65.

12. Kassenberg, A. (2017). Measuring for SDG. What does it mean for Ireland? Administration, 65, 41-71.

13. Urazgaliev, V., Menshikova, G. (2020). Goals of sustainable development as a manifestation of globalization: new global and domestic trends. SHS Web of Conferences, 74, Art. No. 06031.

14. Biggery, M., Clark, D.A., Ferrannini, A., Mauro, V. (2019). Tracking the Sustainable Development Goals in an 'Integrated' manner: a proposal for a new index to capture synergies and trade-offs between and within goals. World Development, 122, 628-647.

15. Barbier, E.B., Burgess, J.C. (2019). Sustainable Development Goals indicators: analyzing trade-offs and complementarities. World Development,122, 295-305. 
16. Miola A., Schiltz F. (2019). Measuring Sustainable Development Goals Performance: How to monitor policy action in the 2030 agenda implementation. Ecological economics, 164.

17. Hayman R. (2019). The Contribution of Civil Society to Social development in the Gulf and beyond, Development in Practice, 29, 45-50.

18. Petkova, L., Honcharenko, I., Berezina, O., Leschenko, M. (2019). The transnationalisation impact on the development of the national economy of Ukraine. In K.S. Soliman (Ed.). Proceedings of the 34th International Business Information Management Association Conference "Vision 2025: Education Excellence and Management of Innovations through Sustainable Economic Competitive Advantage» (pp. 5695-5711). Madrid: International Business Information Management Association.

19. Petkova, L., Berezina, O., Honcharenko, I., Berezhna, L., Marushchak, D. (2020). Management of the national economy productivity: the experience of European integration. The International Conference on Sustainable Futures: Environmental, Technological, Social and Economic Matters (ICSF 2020). E3S Web of Conferences 166, Art. No. 13014.

20. Sustainable Development Goals: Ukraine. National Baseline Report. (2017). Kyiv: Ministry of economic development and trade of Ukraine. 176.

21. National Bank of Ukraine. Macroeconomic indicators. Retrieved from: https://bank.gov.ua/ua/statistic/macro-indicators

22. National Bank of Ukraine Macroeconomic indicators. Statistic of the external sector. Retrieved from: https://bank.gov.ua/statistic/sector-external/data-sector-external\#3

23. State Statistics Service of Ukraine. Retrieve from: https://ukrstat.org/uk

24. Sustainable development strategy “Ukraine-2020”. (2015). Retrieved from: http://zakon5.rada.gov.ua/laws/show/5/2015 \# n10.

25. Petkova, L.O., Berezina, O.Yu, Kryński, A. (2018). Global Partnership for Local Sustainable Development: Modern Trends and Best Practices. Czestochowa: "Educator" Wydawnictwo Akademii Polonijnej. 